\title{
Mulching and Irrigation Practices on Cocoa Seedling Survival and Field Establishment
}

\section{M. Akpalu (Corresponding Author)}

Department of Ecological Agriculture, Bolgatanga Technical University, UER, Ghana Email: aa.marilyn@yahoo.com

\section{G. K. Ofosu-Budu}

Department of Crop Science, University of Ghana, Legon

\section{F. K. Kumaga}

Department of Crop Science, University of Ghana, Legon

\section{K. Ofori}

Department of Crop Science, University of Ghana, Legon

\section{E. Oppong-Danso}

Forest and Horticultural Research Centre-Okumaning, Kade

\section{Article History}

Received: September 5, 2020

Revised: October 10, 2020

Accepted: October 18, 2020

Published: October 22, 2020

Copyright (C) 2020 ARPG \& Author

This work is licensed under the Creative Commons Attribution Internationa

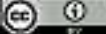

BY: Creative Commons Attribution License 4.0

\begin{abstract}
Irrigation experiments of cocoa tend to concentrate on yield of matured cocoa trees compared to field establishment of young seedlings. Seedling survival leading to optimum population density are fundamental to obtaining maximum yield of crops. The aim of this experiment was to determine the effect of mulching and irrigation on survival of hybrid cocoa clone raised in three different growing media during the establishment phase. The experimental design was a 2 x 2 x 3 factorial arranged in a split-split plot design, with irrigation as the main plot factor, mulching as the subplot factor and growing media as the sub-sub plot factor with three replications. Cocoa pod husk $(\mathrm{CPH})$ was used as the mulching material and each plant received $5 \mathrm{~kg}$ at a rate of $5.6 \mathrm{t} / \mathrm{ha}$. Irrigation was done daily by applying $4 \mathrm{~L}$ of water except when it rains. Data was collected on soil moisture, plant height, leaf number, stem girth and plant survival. Results indicated that irrigation and mulching significantly $(\mathrm{P}<0.01)$ enhanced soil moisture. Cocoa seedlings raised in topsoil, mulched and irrigated significantly $(\mathrm{P}<0.05)$ increased survival rate $(94.5 \%)$ compared to seedlings raised in soil without irrigation and no mulching (47.1\%). Similarly, the survival rate of seedlings raised in growing media M2, mulched and irrigated $(93.0 \%)$ was significantly $(\mathrm{P}<0.05)$ higher than similar seedlings without irrigation $(73.4 \%)$. However, the survival rate of seedlings raised in M3 without mulching but irrigated was significantly $(<0.05)$ higher $92.1 \%$ compared to seedlings raised in M3 mulched and irrigated $67.1 \%$. Irrigation is very important in ensuring high survival rate during early field establishment. Mulching with cocoa pod husk without irrigation did not improve cocoa seedling survival.
\end{abstract}

Keywords: Cocoa; Irrigation; Mulching; Survival; Field establishment; Ghana.

\section{Introduction}

Cocoa has been the key export commodity and foreign exchange earner for the country's development, economic reforms and poverty reduction since independence of Ghana in 1957 Kolavalli and Vigneri [1]. The economy of Ghana will continue to depend on cocoa cultivation as the primary contributor to GDP, sustaining growth and for achieving Middle Income Status (MIC) [2]. Ghana achieved its historic peak production of one million mt during the 2010/2011 season but could not maintain this achievement. The reduction in productivity of the cocoa sector in Ghana could jolt the livelihood of 800,000 to 1 million smallholder farmers [3].

Moreover, due to constant demand for cocoa, the production is being faced with a triple challenge of intensifying productivity on restricted land acreage, reduction of burden on forests ecosystems and intensifying resilience to climate change globally [4] Again, in West Africa, improvement and replacement of existing trees are necessary due to aging tree stocks and pest-infected trees. It is estimates that $23 \%(368,000$ hectares) of Ghana's area under cocoa cultivation is over 30 years old, and at least $17 \%$ (272,000 hectares) is damaged by cocoa swollen shoot virus disease (CSSVD) [5]. Most of the area with aging trees and every one of the CSSVD-affected area is in need of replanting. The Ghana government policies towards accelerated growth in cocoa production in the country is to ensure that Ghana continues to play an important role in the global cocoa economy [5].

Mulching conserves soil moisture by preventing evaporation from the soil surface and reduces erosion from runoff. Crop residues used as mulch might be loaded with organic matter, which is good enough for plant growth [6]. Mulumba and Lal [7], showed that mulch rate significantly affect available water capacity of the soil by $18-35 \%$. Seedling survival and establishment of E. trachycaulus and L. luwisii was improved by $80 \%$ and $88 \%$ respectively when low straw and hay mulch was applied [8].

The use of irrigation increase soil moisture and provides an additional promising path towards improved establishment of plants [9]. Most irrigation experiments on cocoa focused on yields than field establishment, but 
seedling survival leading to optimum population density is fundamental to obtaining maximum yield of crops. Famuwagun, et al. [10], pointed out that robust agronomic practices such as mulching and irrigation are needed to manage cocoa plantation establishment.

The aim of this experiment was to determine the effect of mulching and irrigation on growth and survival of cocoa seedlings during the dry season.

\section{Methodology}

\subsection{Land Preparation and Planting}

The site was slashed, cleared and stumps removed using pickaxe and the stumps packed at the edge of the field, and leaves were allowed to rot. The land was left for 3 weeks of which weeds blocks (replications) which were lined and pegged. Plantain suckers produced under plantain sucker multiplication in polybags were obtained at FOHCREC nursery planted one month before transplanting the cocoa seedlings.

\subsection{Soil Sampling}

Soil samples were collected at random at six different points in the field, using an auger, at a depth of $0-20 \mathrm{~cm}$ and $20 \mathrm{~cm}-40 \mathrm{~cm}$ which were analysed in the laboratory for chemical and physical properties.

\subsection{Transplanting Cocoa Seedlings}

Six-month-old cocoa seedlings were transported from University of Ghana farms to FOHCREC, the seedlings were hardened by reducing the nursery shade for 8 days before transplanting at the field. The cocoa seedlings were planted at a spacing of $3 \mathrm{~m} \times 3 \mathrm{~m}$ to holes that were dug to $25 \mathrm{~cm}$ deep.

A plot consisted of fifteen plants ( $5 \times 3$ planted in a rectangular fashion) and data was taken on the seedlings in the middle, bordered by 12 plants. Each plot size measured $45 \mathrm{~m}$ x $45 \mathrm{~m}$ and contiguous to other treatments plots and the distance between plots was $3 \mathrm{~m}$. The experiment was replicated three times with 180 plants per replicate making a total of 540 plants.

\subsection{Experimental Design and Treatments}

The experimental design was a $2 \times 2 \times 3$ factorial arranged in a split-split plot design, with irrigation as the main plot factor, mulching as the subplot factor and growing media as the sub-sub plot factor with three replications. There were two levels of irrigation on the main plot (Irrigation and No Irrigation), (M-Mulching and NM-No Mulching).

\subsection{Application of Mulch Treatment}

Cocoa pod husk $(\mathrm{CPH})$ was used as the mulching material obtained from the cocoa farm at FOHCREC, the $\mathrm{CPH}$ were collected from a heap that has been left on the farm for three months. The material was applied $5 \mathrm{~cm}$ away from the plant stem to a radius of $60 \mathrm{~cm}$ and thickness of $10 \mathrm{~cm}, 5 \mathrm{~cm}$ away from the plant stem. Each plant received $5 \mathrm{~kg}$ of the mulch material at a rate of $5.6 \mathrm{t} / \mathrm{ha}$.

\subsection{Irrigation Treatment}

Irrigation was done manually, which started on the $4^{\text {th }}$ of January, when it has not rain for two weeks. Irrigation was done daily by applying $4 \mathrm{~L}$ of water to each plant, except when it rains and if the crop evapotranspiration $\left(\mathrm{ET}_{\mathrm{C}}\right)$ exceeds the deficit. The quantity of water applied was calculated using the following equation: $\mathrm{V}_{0}=\mathrm{A} \times \mathrm{ET}_{\mathrm{C}} \mathrm{x} 1 / \mathrm{AP}$ $x$ Fw [11]. Reference evapotranspiration (ETo) of the growing season were calculated following the FAO 56 paper (Penman-Monteith equation) approach using weather data accessed from an installed automatic weather station at the FOHCREC.

\subsection{Data Collection and Analysis}

Data was collected on plant survival, plant height, leaf number, stem girth and soil moisture was measured using Time Domain Reflectometry (TDR), on probes installed $5 \mathrm{~cm}$ away at root zone of the plants early in the morning before the sun rises.

The data was analysed using GenStat Twelfth Edition statistical package PL 20.1 (VSN International Ltd), using ANOVA in a split-split plot model. Percentages reduction in survival between Irrigation and No - irrigation was calculated as follows: $\mathrm{MD}=(\mathrm{I}-\mathrm{NI}) \times 100 / \mathrm{I}$, where $\mathrm{I}$ is irrigation and $\mathrm{NI}$ is no-irrigation.

\section{Results}

The climatic data from January to June 2019 is presented in Table 1; the climatic condition showed that there was severe drought in January where there was no rainfall at all. In February there was some amount of rainfall which was $<100 \mathrm{~mm}$ and it continued in March to April with slight increase in rainfall amounting to $>100 \mathrm{~mm}$. However, the rainfall figures doubled in May and June that is the peak period of rainfall in the experimental area. 
Table-1. Climatic data from January to June 2019

\begin{tabular}{l|l|l|l|l|l|l|l}
\hline Months & $\begin{array}{l}\text { Mean } \\
\text { Rainfall } \\
(\mathbf{m m})\end{array}$ & \multicolumn{2}{l}{$\begin{array}{l}\text { Mean } \\
\text { Temperature }\left({ }^{\mathbf{0}} \mathbf{C}\right)\end{array}$} & \multicolumn{2}{l|}{ Mean RH (\%) } & $\begin{array}{l}\text { Solar } \\
\text { Radiation } \\
\left(\mathbf{M J ~ m}^{-2}\right)\end{array}$ & $\begin{array}{l}\text { Mean Wind } \\
\text { Speed (m/s) }\end{array}$ \\
\hline & & Max & Min & Max (Night) & Min (Day) & & \\
\hline January & 0.0 & 35.0 & 22.0 & 99.8 & 41.5 & 12.2 & 0.35 \\
\hline February & 87.4 & 36.9 & 21.7 & 99.9 & 49.8 & 14.6 & 0.30 \\
\hline March & 107.4 & 35.7 & 22.4 & 99.5 & 47.5 & 15.6 & 0.34 \\
\hline April & 110.5 & 35.4 & 22.7 & 100.0 & 54.3 & 16.1 & 0.33 \\
\hline May & 206.5 & 34.0 & 22.8 & 100.0 & 58.1 & 14.4 & 0.28 \\
\hline June & 260.6 & 31.8 & 22.6 & 99.9 & 64.0 & 12.2 & 0.31 \\
\hline
\end{tabular}

\subsection{Soil Moisture under Irrigation and Mulch Treatment at Root Zone of Cocoa Plants}

Figure one shows the result of the interaction between irrigation, mulching and growing media effect on soil moisture content at the root zone of the plants. The interactive effect was highly significant $(\mathrm{P}<0.01)$, soil moisture content under irrigation $\mathrm{x}$ mulch $\mathrm{x}$ M3 was significantly higher $(105.4 \mathrm{~mm})$ compared to irrigation $\mathrm{x}$ no mulch $\mathrm{x}$ M3 (75mm).

No irrigation $\mathrm{x}$ mulch $\mathrm{x}$ M1 $(95.1 \mathrm{~mm})$ was significantly higher compared to no irrigation $\mathrm{x}$ no mulch $\mathrm{x}$ M1 $(83.6 \mathrm{~mm})$. However, there was no significant difference in soil moisture content for irrigation $\mathrm{x}$ mulch x M2 (96.9 $\mathrm{mm})$ and irrigation x no mulch x M2 (91.9 mm).

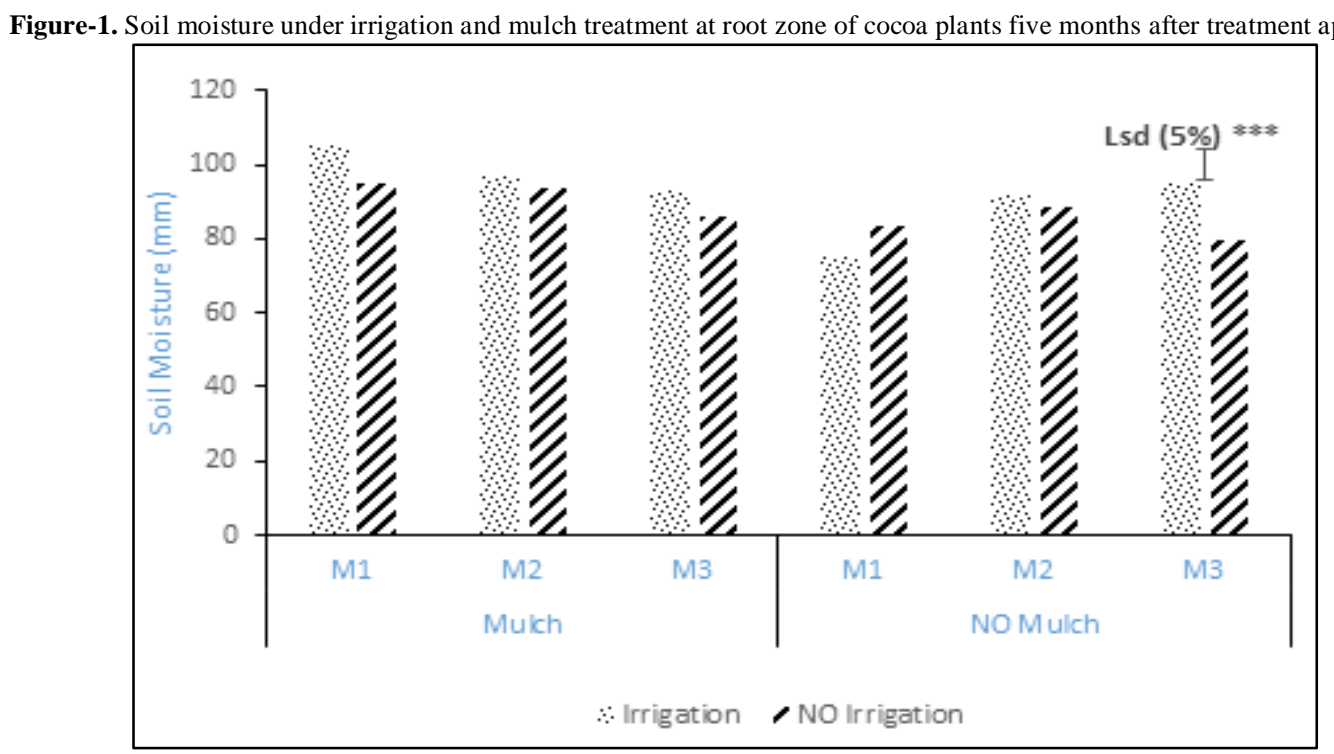

\subsection{Effect of Irrigation and Mulching on Cocoa Seedling Survival and Establishment During the Dry Season}

Seedling survival under irrigation was significantly $(\mathrm{P}<0.05)$ high $(89.6 \%)$ whiles no irrigation recorded $(65.6 \%)$ the least based on the main effect. Mulching, on the other hand, did not significantly $(\mathrm{P}>0.05)$ affect cocoa seedling survival. The type of growing media significantly $(\mathrm{P}<0.01)$ affected survival with $\mathrm{M} 2$ recording significantly higher survival percentage $(83.9 \%)$ compared to M1 $(73.4 \%)$ and M7 $(75.5 \%)$ respectively (Table $2 a)$.

The interactive effect of irrigation and growing media significantly $(\mathrm{P}<0.05)$ affected plant survival, the higher number of surviving plants were recorded under irrigation x M1 (90.5\%) whiles no irrigation x M1 recorded (56.4\%). Survival under irrigation x M3 was significantly higher (89.0\%) compared to no irrigation x M3 (62.0\%) (Table 2a).

The interactive effect of irrigation $\mathrm{x}$ mulch $\mathrm{x}$ growing media significantly $(\mathrm{P}<0.05)$ influenced survival. Seedlings transplanted from M1 had a higher number of surviving plants (94.4\%) under irrigation and mulching compared to survival under no irrigation $\mathrm{x}$ mulch $\mathrm{x}$ M1 (47.1\%). M3 x irrigation $\mathrm{x}$ mulch interaction effect was significantly higher on the number of surviving (86.0\%) plants than M3 x no irrigation x mulching (67.1\%). However, the interaction between irrigation x mulching did not significantly affect M2 treated plants. Nevertheless, a significantly higher number of surviving plants were recorded under irrigation x no mulch x M3 (92.1\%) compared to no irrigation x no mulch x M3 (56.8\%) treatment (Table 2a). 
Table-2a. Effect of irrigation $\mathrm{x}$ mulching $\mathrm{x}$ growing media interaction on cocoa seedling survival (percentage) under establishment

\begin{tabular}{l|l|l|l|l|l|l}
\hline \multirow{2}{*}{ Irrigation } & & \multicolumn{2}{l}{ Growing Media } & \multirow{2}{*}{ Mean } & \multirow{2}{*}{ Mean } \\
\cline { 3 - 5 } & & M1 & M2 & M3 & & \\
\hline \multirow{3}{*}{ Irrigation } & Mulch & 94.4 & 93.0 & 86.0 & 91.1 & \multirow{2}{*}{89.6} \\
\cline { 2 - 6 } & No mulch & 86.5 & 85.9 & 92.1 & 88.1 & \\
\cline { 2 - 6 } & Mean & 90.4 & 89.4 & 89.0 & & \\
\hline \multirow{2}{*}{$\begin{array}{l}\text { No } \\
\text { irrigation }\end{array}$} & Mulch & 47.1 & 73.4 & 67.1 & 62.5 & \multirow{2}{*}{65.6} \\
\cline { 2 - 6 } & No mulch & 65.7 & 83.2 & 56.8 & 68.6 & \\
\cline { 2 - 5 } & Mean & 56.4 & 78.3 & 61.9 & & \\
\hline & Mean & 73.4 & 83.9 & 75.5 & & \\
\hline
\end{tabular}

Lsd $(5 \%)$ - Irrigation $=17.3$, Mulching $=13.6$, Growing media $=8.3$, irrigation $\mathrm{x}$ mulch $=15.6$, irrigation $\mathrm{x}$ media $=13.8$, irrigation $\mathrm{x}$ mulch $\mathrm{x}$ media $=19.0$

Table-2b. Effect of mulching x growing media interaction on cocoa seedling survival (percentage) under establishment during the dry sea son

\begin{tabular}{l|l|l|l|l}
\hline \multirow{2}{*}{ Mulch } & Growing Media & M2 & M3 & Mean \\
\cline { 2 - 5 } & M1 & 83.2 & 76.2 & 76.8 \\
\hline Mulch & 70.8 & 84.5 & 74.4 & 78.4 \\
\hline No mulch & 76.1 &
\end{tabular}

\subsection{Percentage Reduction in Survival of Cocoa Seedlings under no Irrigation Treatment}

Percentage reduction in survival accountable to moisture stress was significantly $(\mathrm{P}<0.05)$ lower for M2 $(12.4 \%)$ treated plants compared to the M1 (37.6\%) and M7 (30.4\%). Treatment difference between M1 and M3 was not significant $(\mathrm{P}>0.05)$ (Figure 2).

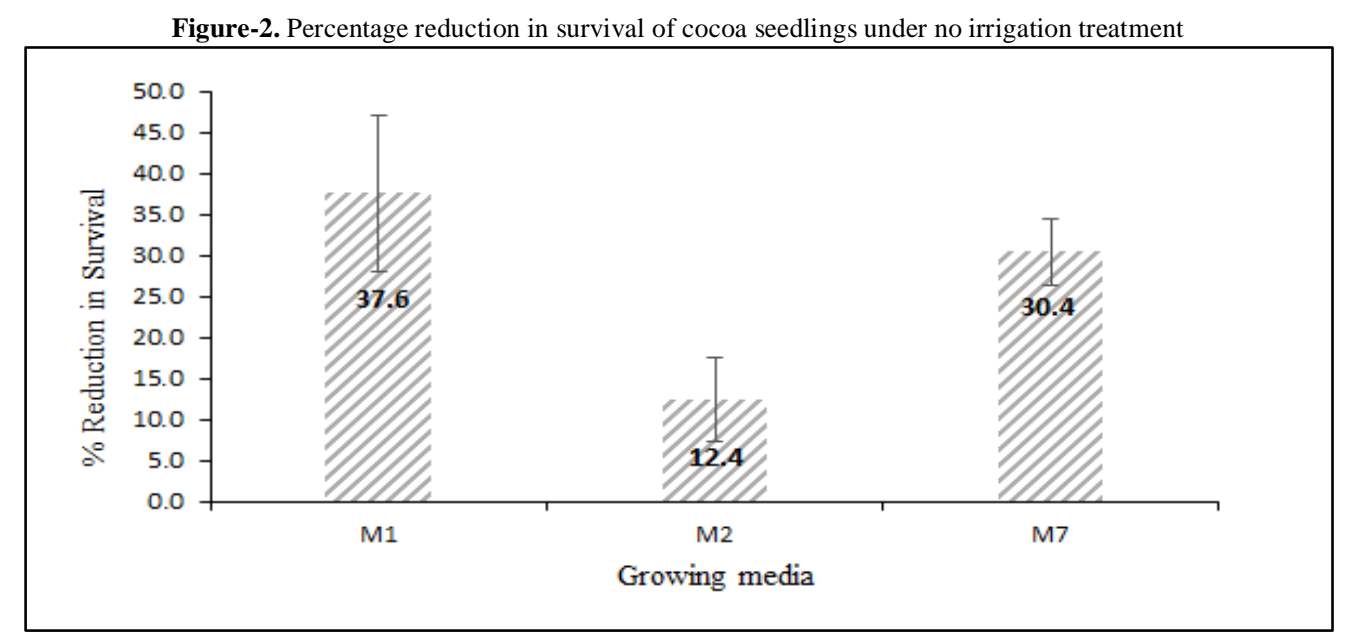

\subsection{Effect of Irrigation and Mulching on Leaf Number}

The interaction between irrigation, mulching and growing did not significantly $(\mathrm{P}<0.05)$ affect the leaf number produced per plants five months after treatment application, however, the leaf number produced reduced by $63.9 \%$ in the M1 treated plants under no irrigation and no mulching. Interestingly, when plants were irrigated but not mulched, leaf number reduced by $34.6 \%$ in M3 treated plants.

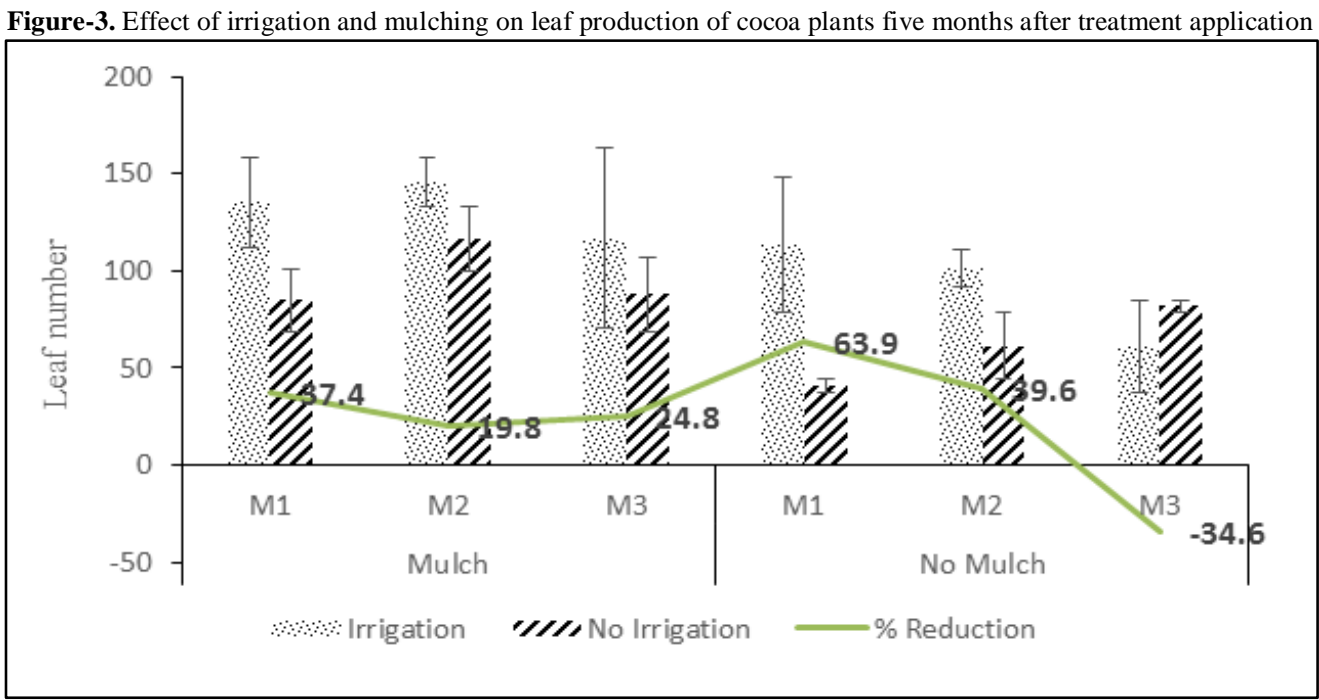




\subsection{Effect of Irrigation and Mulching on Cocoa Plant Height}

Five months after treatment application, the main effect for irrigation treatment was significant $(\mathrm{P}<0.05)$ on plant height. Plants under irrigation were significantly taller $(133.9 \mathrm{~cm})$ than those under no irrigation $(108.3 \mathrm{~cm})$ treatment (Figure 4). Similarly mulching had significant $(\mathrm{P}<0.05)$ effect on plant height, the mean plant height under mulching treatment was significantly higher $(128.3 \mathrm{~cm})$ compared to those under no mulching $(109.4 \mathrm{~cm})$. Plant height was significantly affected by the type of growth media and it was higher for M3 $(129.8 \mathrm{~cm})$ compared to M1 $(104.8 \mathrm{~cm})$ and M2 $(122.0 \mathrm{~cm})$ respectively. However, no significant $(\mathrm{P}>0.05)$ interactive treatment effect was observed. The percentage reduction in plant height under no irrigation but mulched treatment was $33.5 \%, 4.4 \%$ and $15.2 \%$ for GM1, GM2 and GM3, whiles under no mulching and no irrigation, plant height was reduced by $20.7 \%$, $35.2 \%$ and $34.4 \%$ for GM1, GM2 and GM3 respectively.

Figure-4. Effect of irrigation and mulching on cocoa plant height five months after treatment application

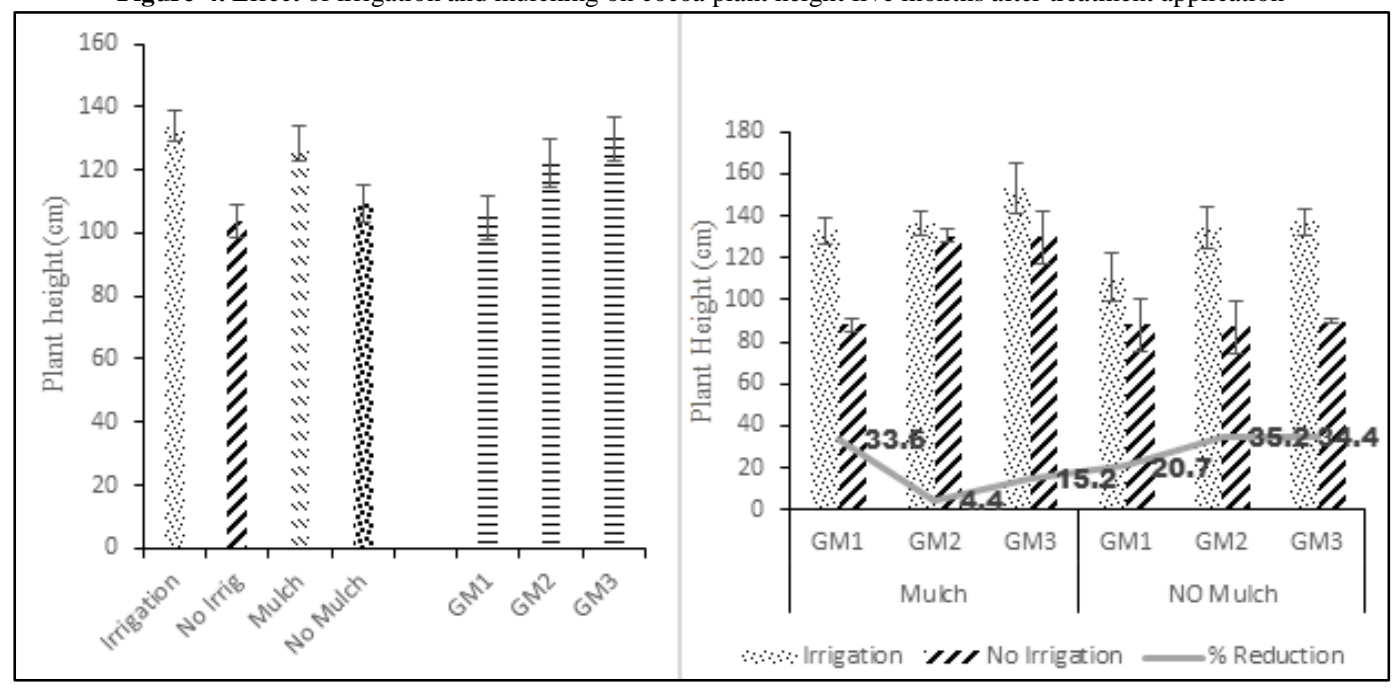

\subsection{Effect of Irrigation and Mulching on Cocoa Plant Stem Girth}

Irrigation on the main effect significantly $(\mathrm{P}<0.05)$ induced thicker stem girth $(2.6 \mathrm{~cm})$ than those under no irrigation $(2.1 \mathrm{~cm})$. The interactive effect of irrigation $\mathrm{x}$ mulching $\mathrm{x}$ growing media did not significantly $(\mathrm{P}>0.05)$ affect stem girth. However, stem girth was reduced by 33.3\%, 13.4\%, and 17.7\% for GM1, GM2 and GM3 treated plants respectively under no irrigation and no mulching treatments. When plants were not irrigated but mulched, stem girth reduced by $14.8 \%, 15.7 \%$ and $18.8 \%$ for GM1, GM2 and GM3 treated plants.

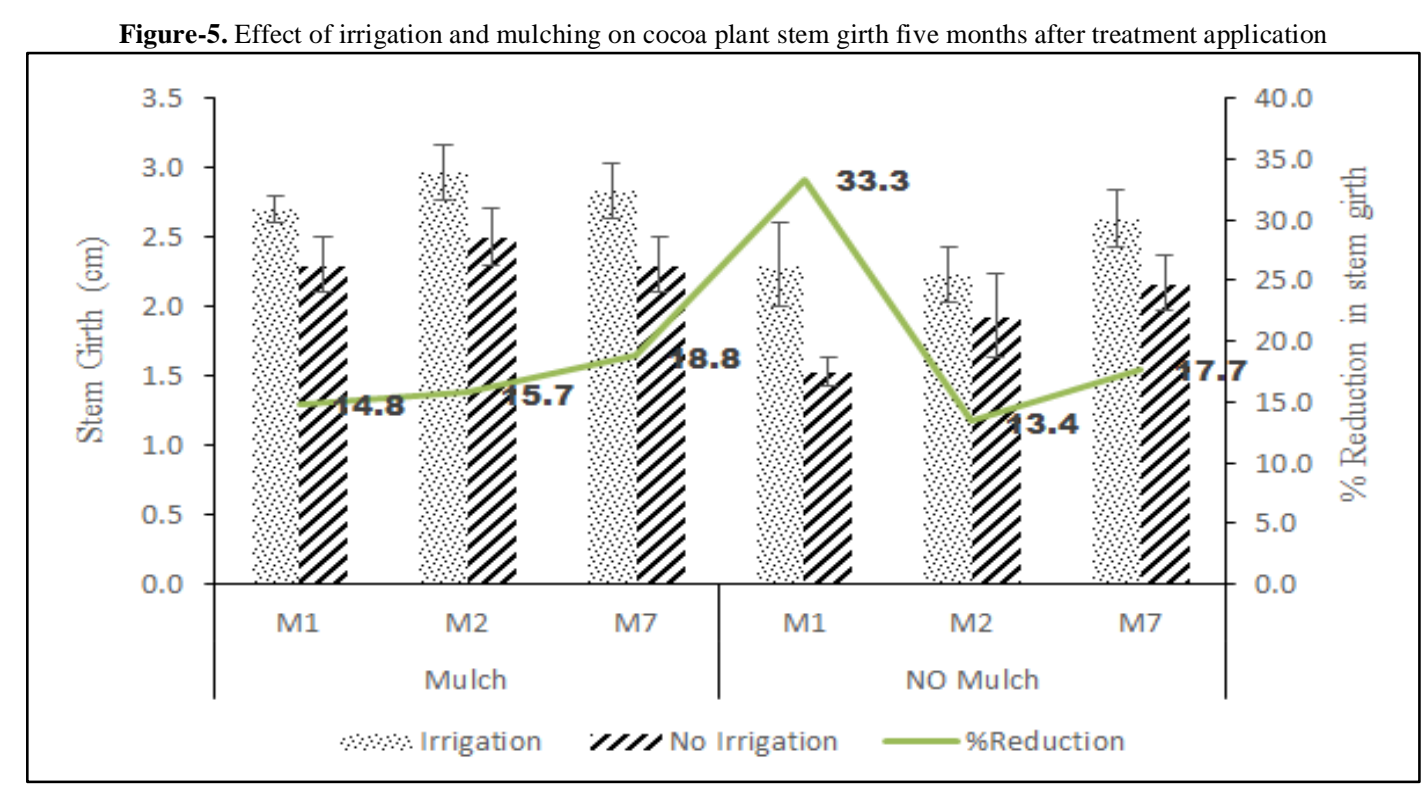

\section{Discussion}

\subsection{The Role of Mulching and Irrigation on Cocoa Seedling Survival and Establishment}

The high survival percentage observed for M1 (90.4\%) under irrigation might be attributed to increased soil moisture when plants were watered than no watering treatment. This survival percentage observed was higher than those reported by Acheampong, et al. [9] who studied field establishment of cocoa under irrigation, mulching plus shading regime and reported $82 \%$ survival rate of PA 150 cocoa genotype under a shade and watering treatment. Moisture availability in soil enhances nutrient uptake by crops and results in good growth and survival. On the other 
hand, survival for M1 under no irrigation was low (56.4\%) and this corroborated with Oppong [12] who recorded $57 \%$ survival of cocoa in marginal cocoa growing areas of Ghana with a prolonged dry season and uneven rainfall conditions.

Survival of seedlings under cocoa pod husk mulch including irrigation x mulching interaction effects did not differ significantly from the no mulch treatment though a significant increase in height, stem girth and leaf number along with high soil moisture content was recorded under the mulch treatment. Similar lack of significant seedling survival under mulching and watering treatment was found by Singer and Martin [13]. Singer and Martin [13] They studied the effect of landscape mulches and drip irrigation on transplant establishment and growth of three North American desert native plants, and reported that the application of mulch was detrimental to growth and survival of brittlebush and four-wing saltbush.

The significant percentage survival observed for M2 (83.9\%) compared to that of M1 and M3 might be due to the bigger seedling size at transplanting [14], and the ability to grow faster and establish before the dry seasons' sets in. Ones this was achieved the plant is able to survive under adverse environmental conditions. This finding agrees with Padi, et al. [15] who conducted an experiment on the differential response of cocoa families to field establishment stress and concluded that seedling size at transplanting might have a positive influence on seedling survival during the dry seasons.

On the other hand, the observation that mulch $\mathrm{x}$ growing media interaction did not have a significant effect on seedling survival might relate to the fact that the mulch material used seemed not to improve seedling survival without irrigation. In the soil medium treated plants, survival reduced by $47.1 \%$ under no irrigation $\mathrm{x}$ mulching treatment compared to no irrigation x no mulching which was 65.7\%. Engelbrecht and Kursar [16], pointed out that seedling mortality might be high even under short dry spells.

Similar irrigation $\mathrm{x}$ mulching $\mathrm{x}$ plant species interactive discrepancies were reported by Silva and Vieira [17] who observed that mulching did not have any significant effect on survival of C.langsdorfii, that only $9 \%$ of the seedlings survived when mulched whiles Eugenia disenterica recorded 99\% survival under no mulching. There is a need to further research into the suitability of cocoa pod materials for mulching cocoa seedlings during the establishment phase.

We would accept the null hypothesis that cocoa pod husk mulching without irrigation did not improve cocoa seedling survival when seedlings were transplanted from soil medium under this condition of study. The low survival rate observed might be attributed to the mulch thickness, which could reduce aeration and lower oxygen diffusion thereby causing root damage. Cushman, et al. [18], indicated aeration difficulty accompanying thick and plastic mulch materials.

Adverse effect of mulch materials on soil are also associated with sudden increased in $\mathrm{pH}$ that might get to alkaline medium and reduce obtainability of micronutrients by plants [19].

Soil moisture at $40 \mathrm{~cm}$ depth was significantly higher for mulch treated plants that also resulted in taller plants with thicker stems than those under no mulch treatment. It is generally agreed upon that mulching boost soil moisture by lowering evaporation from the soil surface and accelerating water infiltration into the soil. Singer and Martin [13], was of the view that mulches would only conserve soil moisture if rainfall amount was enough to penetrate the mulch layer or if irrigation was used.

Further research is required to survey potential cocoa growing areas and identification of water sources that do not dry during the dry season to enable farmers to irrigate the young cocoa during establishment. Limited water sources and inaccessibility to water sources might make irrigation practices difficult to the subsistent cocoa farmer and even on large-scale plantations. Investment in irrigation facilities for the cocoa plantation during the establishment phase may go a long way to benefit fully-grown plantations as watering during flowering and fruiting might improve the yield of cocoa beans. Carr and Lockwood [20], were of a similar view that water relations of cocoa should also have been the topic of most cocoa research programs since the crop is susceptible to drought and is grown in parts of the world that dry season alternates the rainy season.

\section{Conclusion}

Mulching increased soil moisture as usual which reflected positively on seedling growth parameters but did not improve seedling survival. The experiment showed that if cocoa seedlings are raised in soilless media seedling survival could be improved during the dry season. If seedlings are transplanted from the soil, irrigation is essential to improve survival above $90 \%$ for well-established plantations. The study showed that mulching with cocoa pod husk should be done in combination with irrigation to improve seedling survival at the field. Transplanting seedlings from both soil and soilless media, irrigation is essential during the dry season. This require further research to survey potential cocoa growing areas and identification of water sources that do not dry during the dry season and digging of wells to enable farmers to irrigate the young cocoa during the dry season.

\section{Recommendation}

Further research is required to look at the suitability of cocoa pod husk for mulching cocoa seedlings during the establishment phase. The quantity of water to apply and irrigation interval would depend on the prevailing climatic condition of the area. Where watering becomes almost impossible, the soilless medium comprising of SD+PM+RHB (70:25:5) could be used to raise cocoa seedlings for improved survival at the field. There is a need to invest in irrigation facilities in other to boost cocoa establishment and production in the country. 


\section{References}

[1] Kolavalli, S. and Vigneri, M., 2011. Cocoa in Ghana: Shaping the success of an economy. In Yes Africa Can, pp. 201-217.

[2] Breisinger, C., Diao, X., Kolavalli, S., and Thurlow, J., 2008. "The Role of Cocoa in Ghana's Future Development: GSSP Background Paper NO. 0011. IFPRI. In Communications."

[3] Okoffo, E. D., Denkyirah, E. K., Adu, D. T., and Fosu-Mensah, B. Y., 2016. "A double-hurdle model estimation of cocoa farmers' willingness to pay for crop insurance in Ghana." SpringerPlus, vol. 5, pp. 119. Available: https://doi.org/10.1186/s40064-016-2561-2

[4] Streck, C., Alan, K., Simon, K., and A, T., 2017. "Forest and climate-smart cocoa in cote d'ivoire and ghana, aligninig stakeholders to support smallholders in deforestation-freecocoa. World bank, Washington, DC. Report." pp. 1-57.

[5] Oppong, 2016. Ghana government policies towards accelerated growth in Cocoa production. Cocobod, pp. 1-19.

[6] Turmel, M. S., Speratti, A., Baudron, F., Verhulst, N., and Govaerts, B., 2015. "Crop residue management and soil health: A systems analysis." Agricultural Systems, vol. 134, pp. 6-16. Available: https://doi.org/10.1016/j.agsy.2014.05.009

[7] Mulumba, L. N. and Lal, R., 2008. "Mulching effects on selected soil physical properties." Soil and Tillage Research, vol. 98, pp. 106-111. Available: https://doi.org/10.1016/j.still.2007.10.011

[8] Mollard, F. P. O., Naeth, M. A., and Cohen-Fernandez, A., 2014. "Impacts of mulch on prairie seedling establishment: Facilitative to inhibitory effects." Ecological Engineering, vol. 64, pp. 377-384. Available: https://doi.org/10.1016/j.ecoleng.2014.01.012

[9] Acheampong, K., Daymond, A. J., and Hadley, P., 2019. "Improving field establishment of cacao, Theobroma cacao, through mulching, irrigation and shading." Experimental Agriculture, pp. 1-15. Available: https://doi.org/10.1017/S0014479718000479

[10] Famuwagun, I. B., Agele, S. O., and Aiyelari, O. P., 2018. "Shade effects on growth and development of cacao following two years of continuous dry season irrigation." International Journal of Fruit Science, vol. 18, pp. 153-176. Available: https://doi.org/10.1080/15538362.2017.1416326

[11] Allen, R. G., Perieira, L. S., Raes, D., and Smith, M., 2006. "Irrigation and Drainage Paper No. 56: Guides lines for computing crop water requirements." Crop Evapotranspiration, vol. 56, pp. 18-40.

[12] Oppong, 2007. "Comparison of methods of field planting on cocoa seedling survival and early growth in a marginal cocoa-growing area of Ghana." Ghana Journal of Agricultural Science, vol. 40, pp. 199-205.

[13] Singer, C. K. and Martin, C. A., 2009. "Effect of landscape mulches and drip irrigation on transplant establishment and growth of three North American desert native plants 1." J. Environ. Hort., vol. 27, pp. 166-170.

[14] Akpalu, M. M., Ofosu-Budu, G. K., Kumaga, F. K., Ofori, K., and Ofori, A., 2020. "Effect of substrates and fertilizer application rates on growth of two cocoa clones." IOSR Journal of Agriculture and Veterinary Science IOSR-JAVS, vol. 13, pp. 30-43. Available: https://doi.org/10.9790/2380-1308013043

[15] Padi, F. K., Adu-Gyamfi, P., Akpertey, A., Arthur, A., and Ofori, A., 2013. "Differential response of cocoa (Theobroma cacao) families to field establishment stress." Plant Breeding, vol. 132, pp. 229-236. Available: https://doi.org/10.1111/pbr.12039

[16] Engelbrecht, B. M. J. and Kursar, T. A., 2003. "Comparative drought-resistance of seedlings of 28 species of co-occurring tropical woody plants." Oecologia, vol. 136, pp. 383-393. Available: https://doi.org/10.1007/s00442-003-1290-8

[17] Silva, R. R. P. and Vieira, D. L. M., 2017. "Direct seeding of 16 Brazilian savanna trees: responses to seed burial, mulching and an invasive grass." Applied Vegetation Science, vol. 20, pp. 410-421. Available: https://doi.org/10.1111/avsc. 12305

[18] Cushman, K. E., Maqbool, M., and Gerard, P. D., 2005. "Mulch type , mulch depth , and rhizome planting depth for field-grown american mayapple." HortiScience, vol. 40, pp. 635-639.

[19] Carmo, D. L., de Lima, L. B., and Silva, C. A., 2016. "Soil fertility and electrical conductivity affected by organic waste rates and nutrient inputs davi lopes." Revista Brasileira de Ciencia Do Solo, vol. 40, pp. 1-17. Available: https://doi.org/10.1590/18069657rbcs20150152

[20] Carr, M. K. V. and Lockwood, G., 2011. "The water relations and irrigation requirments of cocoa (theobroma cacao L.): A review." Experimental Agriculture, vol. 47, pp. 653-676. Available: https://doi.org/10.1017/S0014479711000421 